\title{
Examining the Most and Least Changeable Elements of the Social Representation of Giftedness
}

\author{
Josué Pérez ${ }^{1, *}$, Leire Aperribai ${ }^{2, *} \mathbb{*}$, Lorea Cortabarría ${ }^{3}\left[\right.$ and Africa Borges ${ }^{1}$ (D) \\ 1 Department of Clinical Psychology, Psychobiology and Methodology, Universidad de La Laguna, \\ 38205 Santa Cruz de Tenerife, Spain; aborges@ull.edu.es \\ 2 Department of Psychology, University of the Basque Country UPV/EHU, \\ 20018 Donostia-San Sebastián, Spain \\ 3 Department of Education, University of the Basque Country UPV/EHU, 01006 Vitoria-Gasteiz, Spain; \\ lorea.cortabarria@ehu.eus \\ * Correspondence: jperez.psicologia@outlook.es (J.P.); leire.aperribai@ehu.eus (L.A.); \\ Tel.: +34-943015656 (L.A.)
}

Received: 27 April 2020; Accepted: 1 July 2020; Published: 2 July 2020

\begin{abstract}
Giftedness and high abilities have been broadly defined and this fact has led to many problems related to the detection and educational response given to gifted or highly able pupils due to the stereotyped social representations of the concepts. However, the main misconceptions might be changed with the aim of solving the mentioned problems. For this purpose, the aims of this study are to explore the main misconceptions of giftedness and to identify which among them seem to be most and least changeable. A questionnaire with the most extended myths and stereotypes about giftedness was applied in a sample of 824 participants. The items' analyses were carried out by first studying item-test discrimination indices (test classical theory), and secondly, the $\mathrm{a}$ and $\mathrm{b}$ parameters of items (item response theory). The results show that there are items that would be easily changeable ( 9 items) and others less malleable (4 items). Therefore, it might be concluded that the social representation of giftedness would have peripheral elements that could be changed, while there would be less malleable central elements. Thus, different strategies to foster the change of the social representation of giftedness should be considered, which will have social and educational implications.
\end{abstract}

Keywords: change; elements; giftedness; social representation

\section{Introduction}

Knowledge about the phenomenon of high ability is constantly changing due to the intense debate that has been taking place at the theoretical level in recent decades. Far from shedding light, this variety of models and conceptions may favor the existence and persistence of stereotypes, representations, or myths that affect, among others, the educational response that these students receive [1].

Myths arise from a combination of false beliefs or ideas shared by the general population, adding experiences and perceptions in everyday reality. Therefore, they are often difficult to modify once they have been assumed [2]. According to Tourón, Fernández, and Reyero [3], the beliefs that the general population holds about any subject influence our perceptions and judgments about reality. Stereotypes, instead, would be common beliefs about a group that help to save energy when explaining social reality [4]. Brown and Turner [4] state that these are formed by illusory correlations so that individuals relate minority group members to unusual behaviors (frequently undesirable) when no real or implicit relationship exists. Stereotypes remain due to priming or the activation of representations (also called implicit memory or accessibility to categories) where a certain social category may be 
activated (consciously or unconsciously) and lead individuals to judge others' behaviors as associated with the characteristics of the category. Moreover, the activation of a certain category decreases the possibility of activating another category [4]. Despite this fact, García-Marqués, Santos, and Mackie [4] consider that stereotypes could be malleable, especially when these are not central nor important or the attribution is related to a nontypical member of the group. This is an important issue, considering that attitudes show three main related components [4]: stereotypes (cognitive), prejudice (affective), and discrimination (behavioral). Therefore, changes in attitude imply previous changes in its cognitive and affective components. Thus, an inappropriate attitude towards giftedness or high ability might be altered by eradicating myths, stereotypes, and prejudices.

There are various myths and stereotypes collected in the literature on this subject that refer to academic aspects, social and personal adjustment, the nature of giftedness, or physical characteristics [5-9]. A key task in the analysis and study of these daily conceptions is to focus on scientific, media and cultural knowledge since it determines how society in general, and teachers in particular, perceive and build their own beliefs or myths about students with high abilities. In the scientific field, for example, the concept of giftedness is diverse to the extent that it depends closely on the basic theoretical model used when trying to conceptualize this phenomenon, with intelligence-centered, cognitive, performance-oriented, and socio-cultural models [10]. This difference in conceptualization entails different interpretations that depend on the diversity of the underlying models, coinciding with what McCallister, Nash, and Meckstroth [11] call "sampling error". Thus, under the same label, hugely different approaches are accepted so that the study group of one research may not be comparable with that of another. Despite the years of research dedicated to scientifically studying giftedness and high abilities, there is still a lack of a general definition of giftedness, and, depending on the model followed, criteria for identifying gifted participants may vary, making the generalizability of research findings difficult [12]. Models have gone from a static or fixed capacity view of potential and intelligence and a purely cognitive understanding of giftedness to a more dynamic perspective where endogenous and exogenous factors are interconnected, leading to a broader concept of talent development [13]. Therefore, a unified and researcher-usable definition would help to improve the quality and external validity of the studies [12].

\subsection{Misconceptions about Giftedness and High Abilities due to Methodological Limitations}

In respect of the educational field, establishing a concrete definition of high abilities or giftedness is also a complicated issue given this variety of perspectives [14] and the lack of agreement on the definition generates even more confusion [15]. Moreover, this diversity of models entails important difficulties from a practical and also economic point of view, since it implies different criteria for inclusion or exclusion depending on the model assumed in the educational policy of each country and even of each region [16]. Therefore, Borges, Hernández-Jorge, and Rodríguez-Naveiras [7] assumed that it is logical that even today, myths still exist and persist in the representation that the general population, and ultimately teachers and other educational agents, have about students with high abilities. As these authors point out, the continuity of these myths about high ability does not favor an adequate knowledge of this type of student, influencing the identification and diagnosis of these children at school [17], and in the same way, making it hard to identify them and to provide these students with high abilities with an educational response adapted to their needs [18].

Many factors contribute to the persistence of incorrect conceptions of high abilities or giftedness among the general population and educational, social, and political agents. The research developed with methodological inaccuracy might have had a crucial role. On the one hand, there are many methodological limitations related to data collecting procedures or biases in selection processes. These could explain the incorrect conception of highly able people as having personal and social adjustment problems, for example. The instruments used to assess the adjustment are not as rigorous as they should be, either because they lack reliability or validity, or because the scales used are not adequate when self-reporting is used. In addition, when data are derived from observations by close associates, whether parents or teachers, prejudices may occur due to problems of subjectivity [11]. 
In terms of selection bias, the research that has probably yielded the most positive results (e.g., those carried out in summer camps) has followed a criterion of participant acceptance based on academic performance [19-22], excluding low-performing gifted pupils, whose personal adjustment and levels of self-esteem might not coincide with those of high academic performance.

On the other hand, studies have argued that a high incidence of psychopathology or predisposition to adjustment problems in gifted children is also not free of methodological problems. The literature is replete with reports of gifted youngsters who refuse to go to school, feel lonely, depressed, and anxious, have low self-esteem, and feel different [23,24]. Much of this literature is based on case studies, anecdotes, programs, and expert opinions [25]. Consequently, the origin of the myth that smart children are clinically problematic may be in the reference sources when these are based on clinical studies. It can be deduced that the gifted child is not a presumed candidate for behavioral or psychopathological problems, but that in some cases, people who request counseling show a peculiar intelligence as one more feature. It is, therefore, a different group, which has come to be called double-diagnosed or exceptional [26]. The clinical pathological "view" biases the vision of the gifted as not having specific needs of emotional features that are different from the nongifted. Therefore, offering a psychoeducational "view" based on the study of "normality" can offer a different vision of this population. However, the most current literature rules out the possibility that people with giftedness, high abilities, or talent, as a group, present problems of personal or social maladjustment different from those of the rest of the population [27-31].

Regarding the methodological weaknesses related to control groups, and from the point of view of scientific rigor, these have not always been the most suitable. Thus, some studies have not compared gifted youths with adequate control groups of nongifted children, but have contrasted data from samples of gifted youths with normative data reported in test manuals [32-34], or there has not been excessive rigor in the criteria for choosing the control group [11].

\subsection{Misconceptions about High Abilities Studied from the Perspective of the Social Representation Theory}

Considering the perspective of the social representation theory [35], there are only a few studies related to the social representation of high abilities in which the concept of intelligence has been the predominant element. In this regard, Tavani, Zenasni, and Pereira-Fradin [36] examined the social representation of giftedness. They considered social representation as a social perception and construction of reality made by individuals, where the construction consists of central or core elements and peripheral elements organized in a structure; core or nucleus elements were considered as normative and stable over time, while peripheral elements were understood as protecting or changing factors for the core element. They examined the structure of the social representation of giftedness, and they found differences between those participants that were familiar with gifted children, and those that they were not: the first group represented a central node or nucleus based on the notions of sensitivity, curiosity, and intelligence, while the second group only considered the last notion of intelligence, this last one being a normative element of the social representation of giftedness. In Finland, Räty [37] developed research in which two different representations of intelligence, in the sense of giftedness, were studied among Finnish parents: fathers seemed to recognize the representation of natural giftedness, while mothers seemed to prefer the representation based on the multifariousness of abilities in a trend of supporting social equality. Moreover, Räty, Mononen, and Pykäläinen [38] studied the representation of natural giftedness among parents, where they found differences related to gender and perceived social rank. However, none of them raised the issue of changes in the social representation of high abilities, which is important to face the misconceptions and the problems derived from these, such as serious obstacles in the detection of highly able pupils and the inaccuracy in the educational response given to them. Therefore, the malleability of the central node of the social representation of giftedness is a challenge for the educational research field. 


\subsection{Effects of Misconceptions on the Educational Response Given to Highly Able Students}

All the factors determining methodological and conceptual mistakes foster the permanence of misconceptions, myths, and false beliefs, and have serious consequences in many fields since they can influence teachers' and families' attitudes towards this population. This could interfere in the identification, assessment, and educational response processes and the general development of these pupils [39].

Various studies have shown the persistence of these myths in teachers, such as the one carried out by García-Barrera and De la Flor [40], where 637 secondary education teachers from all over Spain were assessed on these myths or mistaken beliefs. The obtained results revealed that a considerable part of the participants had little knowledge about these students, considering that they stand out in everything and are committed to the task. Valadez, Zambrano, and Borges [41] found that part of the definitions given by teachers corresponded to aspects related to students' greater knowledge.

As pointed out by Rodrigues and De Souza [1], numerous studies show that one of the main reasons why teachers do not implement strategies that meet the educational needs of highly able students is that they base their actions or educational responses on myths and stereotypes, ignoring scientific studies in this field, which, as previously mentioned, may also be contributing to the generation of confusion, and ultimately, the persistence of these myths. It is essential that teachers are trained in high skills to ensure the success of any educational measure adopted since untrained teachers tend to be disinterested in and reject these types of students [42]. As Reis and Renzulli [43] pointed out, poor teacher training in this area causes gifted students to underperform and even drop out of school. Adequate teacher training, free of stereotypes or myths, results in the appropriate use of specific materials for these students [44] and more positive attitudes [3,45,46].

Another practical aspect, both for the family and for the teachers, is that both are the main agents involved in the detection of highly able students, so the existence of misconceptions among them does not favor an exact detection. In the case of teachers, the detection percentage may not reach $9 \%$ of gifted students with low achievement levels [47]. In the case of families, misconceptions also lead to inaccurate detection [48].

In order to foster more inclusive education and a correct educational response directed to the diversity of highly able pupils, a rigorous study of the prevalent social representation of giftedness and high ability (mainly present in educational agents) is completely necessary. It is important to identify from the perspective of the social representation theory [35] those elements of representations, in this case, the most common myths and stereotypes about giftedness, that show different levels of resistance to change or malleability. Specific training program proposals might be delivered for easily modifying inaccurate elements of social representations (e.g., by introducing and activating correct peripheral elements) [49], as well as for hardly changeable incorrect elements of social representations (e.g., by influencing general public opinions and diminishing the effect of central node elements) [50].

The aims of this exploratory study are to examine the main incorrect elements of social representations of high ability or giftedness and to identify, through the item response theory (IRT), which elements among them seem to be most and least changeable.

\section{Materials and Methods}

\subsection{Participants}

In the present study, the sample was composed of 824 participants. Firstly, 313 participants from the general population in Spain participated in the study, 217 being women and 96 men. This was a heterogeneous subsample composed of people of different ages, sex, educational levels, professions, and regions in Spain. They were considered to have a population-based social representation of giftedness. Secondly, 511 university students of preschool and primary Education (years 1 to 3) from a Spanish private teacher training university college participated, from which 341 were women, 167 men, and 3 did not specify their sex. This subsample was included because it was considered important 
to know the social representation of giftedness among the future teachers of preschool and primary education levels. Therefore, considering the whole sample, $67.7 \%$ were women, $31.9 \%$ men, and $0.4 \%$ did not specify their sex. Considering the age of participants, the range was between 16 and 75 years $(M=26.61 ; S D=11.69)$. Finally, in respect of the participants' educational levels, only $21(2.4 \%)$ had primary or secondary level education.

\subsection{Instrument}

Representation of high abilities (giftedness) [51]. This is a short questionnaire to be applied in $10 \mathrm{~min}$ about the representation of high abilities in the educational and more general fields. It consists of 34 items (see Table 1) with a 4-point Likert scale (from "totally disagree" to "totally agree"), where all the statements assess the existing and most common myths and stereotypes about high abilities in literature. The items are based firstly on a previous instrument [8], secondly, on a literature review of the most common myths and stereotypes, and finally, on the judgment and corrections of several experts on the field (as evidence of content validity). The instrument has shown to be reliable (Cronbach's alpha $=0.899$ ) and it assesses a unique dimension (as evidence of construct validity).

Table 1. Representation of high abilities (giftedness) [51]. Myths and stereotypes of giftedness reflected in the items of the questionnaire and their literary sources.

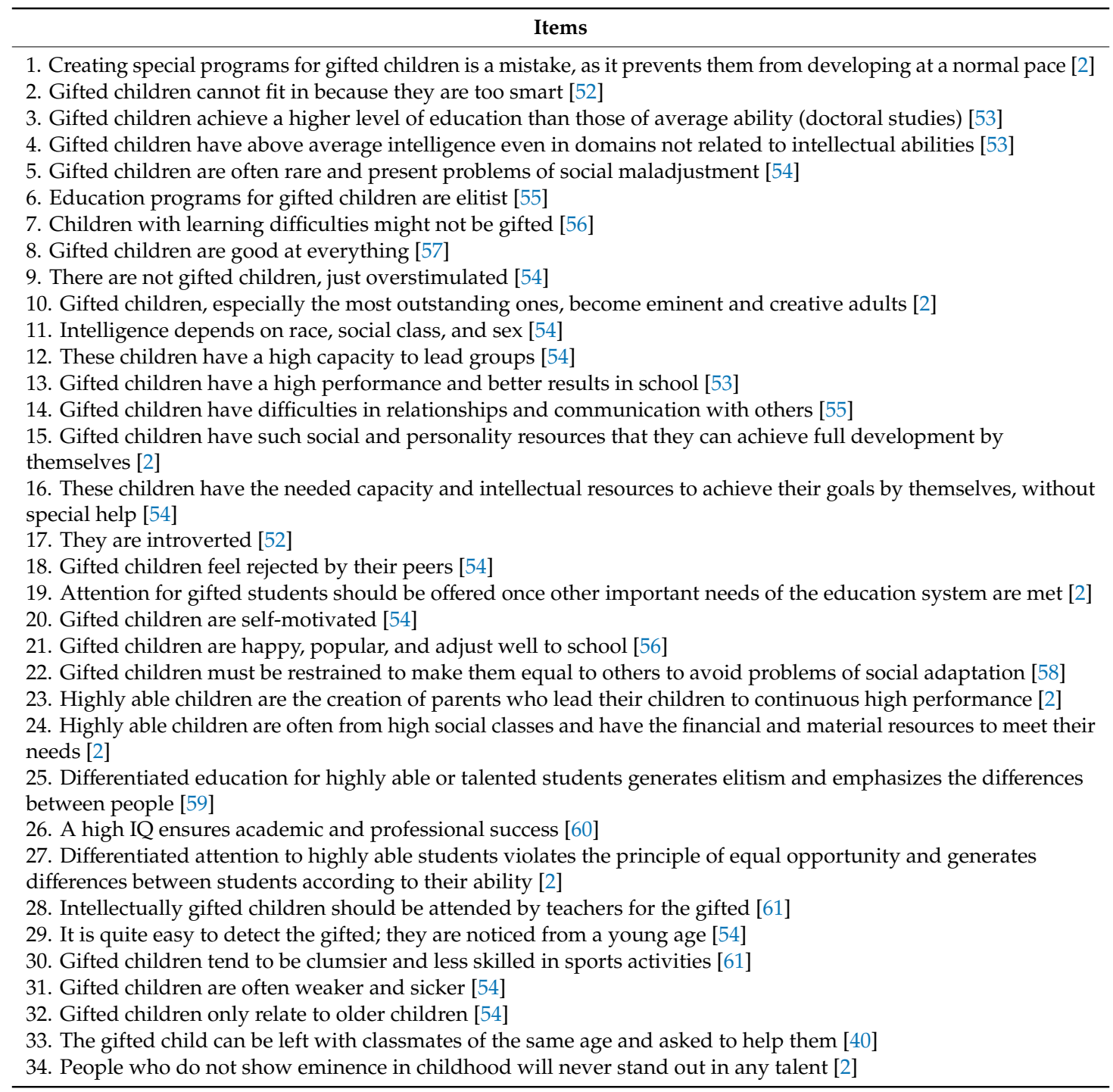




\subsection{Procedure}

The study is based on a cross-sectional design and follows a survey methodology, where an online tool was applied in Google form to a heterogeneous sample of the general population. In addition, it was applied to a sample of preschool and primary education university students at a private teacher training university college during school hours (an average time of $30 \mathrm{~min}$ was estimated).

In order to comply with ethical and data protection requirements, in the first study of the general population, the informed consent of the participants was requested online (prior to the completion of the questionnaires). For the second study, we first obtained the approval of the Ethics Commission of the private university and the permission of the university and the teachers involved; in parallel, the principal researchers obtained approval from their university's Ethics Commission (CEIBA2020-0392). Secondly, the informed consent of the participants was requested following the same protocol as for the general population sample. In both cases, the data were collected anonymously, and no information was required that would lead to the identification of the participants. The data were stored in a repository managed by the principal investigators and will be destroyed within a reasonable time once the results of the study are published.

\subsection{Data Analyses}

In order to corroborate the discrimination values of the items, item-test discrimination indices were calculated with the SPSS v20 program. Moreover, the reliability index of the instrument and the unidimensionality of the factor structure were explored by carrying out a one-factor exploratory factor analysis with the software Factor v10.9.01 [62]. Finally, aiming to explore the malleability of items, these were analyzed based on the item response theory, by determining the $a$ and $b$ parameters with normal-ogive parameterization, and using a graded response model (GRM) [63] with the same program.

\section{Results}

\subsection{Item-Test Discrimination Indices}

The items presented adequate discrimination indices, with a range between 0.226 and 0.537 . Therefore, item correlation with the rest of the scale is acceptable, and this means that the studied myths and stereotypes correspond to the representation of giftedness. These are shown in Table 2.

Table 2. Item-test discrimination indices.

\begin{tabular}{cccccc}
\hline Item & DI & Item & DI & Item & DI \\
\hline 1 & 0.279 & 13 & 0.508 & 25 & 0.373 \\
2 & 0.288 & 14 & 0.315 & 26 & 0.533 \\
3 & 0.442 & 15 & 0.509 & 27 & 0.434 \\
4 & 0.373 & 16 & 0.517 & 28 & 0.396 \\
5 & 0.375 & 17 & 0.394 & 29 & 0.398 \\
6 & 0.319 & 18 & 0.237 & 30 & 0.408 \\
7 & 0.371 & 19 & 0.419 & 31 & 0.514 \\
8 & 0.396 & 20 & 0.512 & 32 & 0.328 \\
9 & 0.380 & 21 & 0.317 & 33 & 0.226 \\
10 & 0.419 & 22 & 0.421 & 34 & 0.457 \\
11 & 0.372 & 23 & 0.537 & & \\
12 & 0.329 & 24 & 0.469 & & \\
\hline
\end{tabular}

\subsection{Factor Structure and Reliability}

In order to determine the unidimensionality of the scale and to compare this one to the structural model of the original instrument [51], exploratory factor analysis was carried out, making the initial matrix with polychoric correlations, and limiting the number of factors to one. The suitability of the factor analysis was verified $(K M O=0.902$; Bartlett's statistic 6915.7, $d f=561 ; p=0.000010)$. The model 
showed to be adequate, with an RMSEA value of 0.071 (thus, between 0.050 and 0.080 ), and a CFI of 0.934 (between 0.920 and 0.950 ). The factor extracted explained $0.27503 \%$ of the variance. The omega coefficient obtained confirmed the good reliability of the instrument (McDonald's omega $=0.913$ ). The factorial weights of the items are shown in Table 3. In sum, psychometric properties in this study correspond to those found in the original study, verifying the unique structure of the instrument and its reliability, as well as the scientific value of the tool and the study.

Table 3. Factorial weights of the items.

\begin{tabular}{cccccc}
\hline Item & Weight & Item & Weight & Item & Weight \\
\hline 1 & 0.351 & 13 & 0.591 & 25 & 0.424 \\
2 & 0.381 & 14 & 0.316 & 26 & 0.675 \\
3 & 0.508 & 15 & 0.602 & 27 & 0.497 \\
4 & 0.438 & 16 & 0.613 & 28 & 0.532 \\
5 & 0.403 & 17 & 0.427 & 29 & 0.464 \\
6 & 0.343 & 18 & 0.234 & 30 & 0.482 \\
7 & 0.487 & 19 & 0.501 & 31 & 0.636 \\
8 & 0.555 & 20 & 0.643 & 32 & 0.390 \\
9 & 0.484 & 21 & 0.431 & 33 & 0.249 \\
10 & 0.490 & 22 & 0.608 & 34 & 0.616 \\
11 & 0.579 & 23 & 0.695 & & \\
12 & 0.400 & 24 & 0.635 & & \\
\hline
\end{tabular}

\subsection{Items Analyses Based on the Item Response Theory}

In order to explore the malleability of items, these were analyzed based on the item response theory [64]. Those showing a greater difference between parameters $b_{3}$ and $b_{1}$ (see Table 4) were considered as being less changeable, while those with a small difference were considered as being more changeable.

Table 4. Parameters of items based on the item response theory.

\begin{tabular}{cccccc}
\hline Items & $\mathbf{a}$ & $\mathbf{b}_{\mathbf{1}}$ & $\mathbf{b}_{\mathbf{2}}$ & $\mathbf{b}_{\mathbf{3}}$ & $\mathbf{b}_{\mathbf{3}}-\mathbf{b}_{\mathbf{1}}$ \\
\hline 1 & 0.374 & -0.121 & 2.125 & 4.506 & 4.627 \\
2 & 0.413 & 1.573 & 3.519 & 5.000 & 3.427 \\
3 & 0.589 & -1.516 & 0.653 & 3.013 & 4.529 \\
4 & 0.487 & -0.793 & 1.514 & 3.902 & 4.695 \\
5 & 0.441 & -1.199 & 1.345 & 4.484 & 5.683 \\
6 & 0.365 & -2.079 & 1.137 & 4.192 & 6.271 \\
7 & 0.558 & 0.301 & 2.449 & 3.653 & 3.352 \\
8 & 0.668 & 1.113 & 2.945 & 4.129 & 3.016 \\
9 & 0.554 & 0.094 & 2.501 & 4.319 & 4.225 \\
10 & 0.562 & -1.717 & 1.051 & 3.830 & 5.547 \\
11 & 0.709 & 1.861 & 3.075 & 4.335 & 2.474 \\
12 & 0.437 & -1.064 & 2.154 & 4.980 & 6.044 \\
13 & 0.732 & -1.337 & 0.406 & 2.162 & 3.499 \\
14 & 0.333 & -3.459 & 0.386 & 4.392 & 7.851 \\
15 & 0.753 & -0.844 & 1.419 & 3.392 & 4.236 \\
16 & 0.775 & -0.767 & 1.095 & 2.880 & 3.647 \\
17 & 0.472 & -2.127 & 0.792 & 3.561 & 5.688 \\
18 & 0.241 & -4.643 & 0.792 & 5.000 & 9.643 \\
19 & 0.579 & -0.598 & 1.097 & 3.052 & 3.650 \\
20 & 0.839 & 0.043 & 1.895 & 3.505 & 3.462 \\
\hline
\end{tabular}


Table 4. Cont.

\begin{tabular}{cccccc}
\hline Items & $\mathbf{a}$ & $\mathbf{b}_{\mathbf{1}}$ & $\mathbf{b}_{\mathbf{2}}$ & $\mathbf{b}_{\mathbf{3}}$ & $\mathbf{b}_{\mathbf{3}}-\mathbf{b}_{\mathbf{1}}$ \\
\hline 21 & 0.478 & -0.635 & 2.722 & 4.984 & 5.619 \\
22 & 0.765 & 1.060 & 2.324 & 3.147 & 2.087 \\
23 & 0.966 & 0.349 & 1.868 & 3.300 & 2.951 \\
24 & 0.823 & 0.767 & 2.304 & 3.757 & 2.990 \\
25 & 0.468 & -1.289 & 0.998 & 3.333 & 4.622 \\
26 & 0.915 & 0.336 & 1.713 & 3.099 & 2.763 \\
27 & 0.573 & -0.725 & 1.142 & 3.096 & 3.821 \\
28 & 0.629 & 0.922 & 2.623 & 4.099 & 3.177 \\
29 & 0.524 & -1.222 & 1.093 & 3.336 & 4.558 \\
30 & 0.551 & -0.278 & 1.825 & 3.817 & 4.095 \\
31 & 0.825 & 0.476 & 2.344 & 3.380 & 2.904 \\
32 & 0.423 & -0.305 & 2.462 & 5.000 & 5.305 \\
33 & 0.257 & -3.550 & 0.012 & 4.591 & 8.141 \\
34 & 0.781 & 0.725 & 2.500 & 3.316 & 2.591 \\
\hline
\end{tabular}

Results show that, on the one hand, considering the a parameter, items 14,18, and 33 have a limited capacity of discrimination. This is partly in accordance with the results found by following the classical test theory (see items 18 and 33 in Table 2). Among the items, 22 have low values, while the rest show moderate values. Therefore, the analyzed myths and stereotypes show low or moderate properties related to the representation of giftedness.

On the other hand, considering the lowest values of the $b_{3}$ parameter, items 13 and 16 have been regarded as being the most changeable. Finally, considering the criteria of the difference between parameters $b_{3}$ and $b_{1}$, the most changeable would be items $11,22,23,24,26,31$ and 34 , while the least changeable would be items $12,14,18$ and 33. In sum, considering the malleability of myths and stereotypes as elements of the social representation of giftedness, these are the items in which researchers and education practitioners should pay attention.

\section{Discussion}

As already stated, in many cases, the popular meanings of talent and high ability are based on misconceptions, which lead to two fundamental problems: understanding high ability as a synonym of high performance, and believing that the presence of high intelligence will inevitably relate to personal or social maladjustments. In the first case, the fundamental problem is the error in detecting these students, especially when those who maintain this belief are teachers [65]. This can lead to excluding highly able students with a low performance. As for the second, the main problem would be the social alarm generated in their families, as parents will receive the diagnosis of high ability with concern because they imagine a future of loneliness and maladjustment for their child [66].

This research has brought, in part, promising results. Thus, the items that have shown a lower score (those that indicate a smaller presence of misconception) are related to academic performance: relating high ability to high performance (item 13) or thinking that the children have the needed resources to achieve their goals (item 16). According to this point but considering the criterion of a lesser difference between parameters $b_{3}$ and $b_{1}$, item 26 states that a high IQ ensures a high performance. Obviously, intelligence and instruction are not interchangeable concepts. Good intelligence facilitates learning, but intelligence does not mean possessing knowledge if the student does not participate in the teaching-learning process. Additionally, within this set of beliefs, there is little difference between parameters $b_{3}$ and $b_{1}$ in considering that gifted pupils must be slowed down to match their peers (item 22) or considering that their talent is the result of parental effort (item 23).

The other group of more malleable contents has to do with the disregard of the social context related to greater intelligence (items 11 and 24) and the idea of their physical weakness (item 31), or the idea that they must show eminence from childhood to excel in some talent (item 34). From a 
perspective of the Social Representation Theory, these would be the items that correspond to peripheral elements with a greater weight than central elements. Therefore, peripheral elements that would bring people to contemplate highly able children closer to their reality should be created and reinforced, so that new activities and elements can become social representations' central elements [49]. In practice, specific intervention programs aiming to show diversity among highly able or talented students could be helpful to introduce new peripheral elements (characteristics) and enhance changes in social representation.

However, despite the contrary evidence that emerges in the literature $[27,28,67,68]$, the myth of the lack of social adjustment still remains, since items 14 and 18, which refer to these contents, seem to have high differences between parameters $b_{3}$ and $b_{1}$, these being less malleable. The idea of being leaders (item 12) also appears to be rooted, and this can be easily explained because when they share a classroom with their less able peers, their greater reasoning capacity would make them stand out as leaders in the group. Although, in specialized literature, the leadership capacity of the gifted or highly able students is assumed [69], evidence shows a lack of relationship between leadership and high ability [70].

Finally, the consideration of letting the gifted child become a tutor to their peers, as good teaching practice (item 33), seems to be less malleable, which is also considered an educational response by their teachers [41]. This strategy may benefit the classroom climate by finding a task for this student, but it would not be helpful from the point of view of the student, because the gifted child would not be receiving the needed educational response. In this case, we are talking about those representations that have a wrong but well-anchored central nucleus, which would require new activities or interventions aimed at a more general population that would generate an influence on public opinion (e.g., by using tactics based on the basic principles of social influence) [50], and thus contribute to diminish the effect of the elements of the central node of the representation.

Intervention programs that have an impact on these less malleable items should be directed towards the general population. Thus, it would be interesting to design campaigns, publicity, or other projects that could help enhance another view of high ability or giftedness into societies.

In social representations, the myths and erroneous beliefs usually appear in many contexts, since they favor the creation of stereotypes, due to physical or external factors or to internal factors [71]. It is not strange that this type of intuitive and simplified knowledge appears in so many fields because, as in any other categorization phenomenon, it introduces order and facilitates the perception of reality [72].

However, the misconception about greater intellectual ability (giftedness, high ability, or talent) does not favor the best development of this group, being especially dangerous for those who deal more closely with these students, that is, parents and teachers. It has been empirically corroborated that stereotypes can determine certain attitudes (e.g., active harm, neglecting or helping) towards the others [73], and teachers are not an exception. Therefore, social representation and the associated myths or beliefs that teachers may have about their students in general and, more specifically, about highly able pupils, depend on many variables, the most relevant being academic preparation and the professional context [74].

It is important to eradicate the idea of the equivalence between high performance and high ability, an aspect often incurring among teachers [65]. The lack of training related to the detection of highly able students and the response that should be given to them generates a lack of knowledge regarding the characteristics of these students (given that the information that they manage is based on misconceptions), and consequently, hinders their detection. On the other hand, the little or lack of training in adapted educational strategies and methodologies makes the educational response deficient. Therefore, the absence of specific training in high skills is not helpful at all. In Spain, as well as in several other countries, the existence of specific content on high abilities is not usual for both undergraduate or graduate studies in the most affected careers, such as teaching, pedagogy, and psychology [75]. Therefore, it is necessary to include rigorous and empirically supported content on this topic in the curricula of these careers. The myths and stereotypes analyzed in this study could be 
considered in the curricula and in other training programs. It would be important to eradicate those by following different strategies for more and less malleable elements and offer a more realistic scope of high ability or giftedness.

With respect to the families, misconceptions can lead to false detection realized by parents. The family plays a fundamental role in the development of the highly able or gifted child, basically by using educational attitudes that generate positive attitudes [76]. In a recent study [48], it was observed that among the reasons given by parents who had considered their children to be gifted but were not confirmed in the diagnosis was that their teachers had nominated them as more able (probably because of good performance, and due to the confusion between academic talent and high ability) than others. On the other hand, it is also important to contradict this myth, due to the concerns that parents may have about their children having problems in their social relationships $[77,78]$. Therefore, training programs for parents of the highly able children would be important to eradicate misconceptions about high ability or giftedness. Moreover, general campaigns directed to other parents, or to educational, social, and political agents would be important to change those misconceptions or erroneous elements (e.g., myths and stereotypes) of the social representation of high abilities. This could have a great impact in society but also in educational and political responses given to highly able people.

Finally, we must admit that this research has not been developed without limitations. Firstly, it would be more representative to extend the sample to public university students. Secondly, it would be interesting to develop the research with other professionals of education, such as primary education teachers. Thirdly, data collected from other sources could provide interesting information about how high abilities are understood in society and could help improving the characteristics of the tools. Thus, conducting qualitative research could be ideal for future research. In respect of other future directions for intervention and research, it is considered important to design different intervention strategies and to study their effects in the change of the social representation of high ability or giftedness. Once the diverse interventions are applied, it would be interesting to continue with research aimed to explore how these changes influence the detection and educational response given to these students, and how these interventions foster the changes in social attitudes towards highly able or gifted people.

\section{Conclusions}

The existence of myths about giftedness, high abilities, and talent is still present and it is important to carry out training, information, and dissemination actions to eliminate them. In the present work, it has become clear that the set of elements of the social representation of high ability or giftedness does not have equal malleability. Thus, there seems to be a greater ability to eliminate elements that consider high ability as equal to high performance, while those related to the inadequate social adaptation of these students are more difficult to eradicate.

The maintenance of these myths or misconceptions has a very clear practical implication: a lack of knowledge about the reality of highly able or gifted students makes their detection more difficult, which is the first step once the presence of a higher ability is corroborated by identification and diagnosis, so that the appropriate educational response can be given. It also interferes in the correct performance, since the lack of knowledge about the characteristics of these students makes the application of favorable learning strategies and methodologies difficult, which only hinders the response given to their personal and educational needs.

In conclusion, it is necessary to give information about the reality of these students to the general population through different tactics of social influence and through the media, social networks, as well as scientific events of diffusion. In addition, given the relevance that teachers play in both the detection and educational response of these students, it is essential that teacher training at both the undergraduate and graduate levels clearly and broadly include content related to the education of highly able pupils.

Author Contributions: Conceptualization, J.P., L.A., L.C., and A.B.; methodology, J.P., L.A., L.C., and A.B.; validation, J.P. and A.B.; formal analysis, A.B.; investigation, J.P., L.A., and L.C.; resources, J.P., L.A., L.C., and A.B.; 
data curation, L.A.; writing—original draft preparation, J.P., L.A., A.B., and L.C.; writing—review and editing, L.A. and L.C.; visualization, L.A. and L.C.; supervision, A.B.; project administration, A.B.; funding acquisition, not applicable. All authors have read and agreed to the published version of the manuscript.

Funding: This research received no external funding.

Acknowledgments: We acknowledge Eduardo García Cueto for the methodological support given.

Conflicts of Interest: The authors declare no conflict of interest.

\section{References}

1. Rodrigues, R.; De Souza, D. Learning acceleration for gifted students: Favorable and unfavorable arguments. Rev. De Psicol. 2012, 30, 190-214.

2. Tourón, J. Mitos y realidades en torno a la alta capacidad. In Alunos Sobredotados. Contributos Para a Sua Identificaçao e Apoio; Almeida, L., Oliveira, E.P., Melo, A.S., Eds.; ANEIS: Braga, Portugal, 2000.

3. Tourón, J.; Fernández, R.; Reyero, M. Actitudes del profesorado hacia la superdotación. Implicaciones para el desarrollo de programas de formación. Faísca 2002, 9, 95-110.

4. Gómez, A. Estereotipos. In Psicología Social, 3rd ed.; Morales, J.F., Moya, M., Gaviria, E., Cuadrado, I., Eds.; McGraw Hill: Madrid, Spain, 2009; pp. 213-241.

5. Callahan, C.M. Beyond the gifted stereotype. Educ. Leadersh. 2001, 59, 42-46.

6. Cross, T.L. Social/Emotional needs: Competing with myths about the social and emotional development of gifted students. Gift. Child Today 2002, 25, 44-65. [CrossRef]

7. Borges, A.; Hernández-Jorge, C.; Rodríguez-Naveiras, E. Superdotación y altas capacidades, tierra de mitos. RIDPSICLO 2009, 3, 1-11.

8. Pérez, J.; Borges, A.; Rodríguez-Naveiras, E. Conocimientos y mitos sobre altas capacidades. TALINCREA 2017, 4, 40-51.

9. Pfeiffer, S.L. Tripartite model of giftedness and best practices in gifted assessment. Rev. Educ. 2015, 368, 66-95. [CrossRef]

10. Borges, A.; Hernández-Jorge, C. La superdotación intelectual: Algo más que un privilegio. Acta Científica Y Tecnológica 2006, 10, 28-33.

11. McCallister, C.; Nash, W.R.; Meckstroth, E. The social competence of gifted children: Experiments and experience. Roeper Rev. 1996, 18, 273-276. [CrossRef]

12. Carman, C.A. Comparing apples and oranges: Fifteen years of definitions of giftedness in research. J. Adv. Acad. 2013, 24, 52-70. [CrossRef]

13. Dai, D.Y. Envisioning a new foundation for gifted education: Evolving Complexity Theory (ECT) of talent development. Gift. Child Q. 2017, 6, 172-182. [CrossRef]

14. Agudo, N. Un estudiante con altas capacidades en mi aula, ¿ahora qué? Rev. Educ. Incl. 2017, 10, $265-277$.

15. Sánchez-Manzano, E. The emerging model of giftedness quad. Rev. De Psicol. Y Educ. 2010, 1, 51-68.

16. Mandelman, S.D.; Tan, M.; Aljughaiman, A.M.; Grigorenko, E.L. Intellectual giftedness: Economic, political, cultural and psychological considerations. Learn. Individ. Differ. 2010, 20, 287-297. [CrossRef]

17. Borges, A. Programas de intervención para alumnado de altas capacidades. In Atención a la Diversidad y Educación Inclusiva Cuestiones Teóricas y Prácticas; López-Aymes, G., Moreno, A.J., Montes-de-Oca-O’Reilly, A., Manríquez, L., Eds.; Fontamara: México City, Mexico, 2017; pp. 211-230.

18. Sánchez-Manzano, E. La superdotación Intelectual; Aljibe: Málaga, Spain, 2009.

19. Davalos, R.A.; Haensly, P.A. After the dust has settled: Youth reflect on their high school mentored research experience. Roeper Rev. 1997, 19, 204-207. [CrossRef]

20. Mills, C.J.; Parker, W.D. Cognitive-psychological profiles of gifted adolescents from Ireland and the U.S.: Cross-societal comparisons. Int. J. Intercult. Relat. 1998, 22, 1-16. [CrossRef]

21. Gallucci, N.T.; Middleton, G.; Kline, A. Intellectually superior children and behavioral problems and competence. Roeper Rev. 1999, 22, 18-21. [CrossRef]

22. Norman, A.D.; Ramsay, S.G.; Roberts, J.; Martray, C.R. Effect of social setting, self-concept and relative age on the social status of moderately and highly gifted students. Roeper Rev. 2000, 23, 34-39. [CrossRef]

23. Montour, K. The marvelous boys: Thomas Chatterton, Evariste Galois and their modern counterparts. Gift. Child Q. 1978, 22, 68-78. [CrossRef] 
24. Cross, T.L.; Coleman, L.J.; Stewart, R.A. The social cognition of gifted adolescents: An exploration of the stigma of giftedness paradigm. Roeper Rev. 1993, 16, 37-40. [CrossRef]

25. Gust, K.L. Is the literature on social and emotional needs empirically based? Gift. Child Today 1997, 20, 12-13. [CrossRef]

26. Mouchiroud, C. Haut potentiel intellectuel et développement social. Psychol. Française 2004, 49, $293-304$. [CrossRef]

27. Borges, A.; Hernández-Jorge, C.; Rodríguez-Naveiras, E. Evidencias contra el mito de la inadaptación de las personas con altas capacidades intelectuales. Psicothema 2011, 23, 362-367.

28. Borges, A.; Hernández-Jorge, M.C.; Rodríguez-Naveiras, E. La adaptación social de niños y niñas de altas capacidades intelectuales: Un acercamiento cualitativo. Sobredotaçao 2008, 9, 119-130.

29. Rodríguez-Naveiras, E.; Borges, A. Programas extraescolares: Una alternativa a la respuesta educativa de altas capacidades. Rev. De Educ. Y Desarro. 2020, 52, 19-27.

30. López, V.; Sotillo, M. Giftedness and social adjustment: Evidence supporting the resilience approach in Spanish-speaking children and adolescents. High Abil. Stud. 2009, 20, 39-53. [CrossRef]

31. Robinson, N.M. The social world of gifted children and youth. In Handbook of Giftedness in Children: Psychoeducational Theory, Research, and Best Practices; Pfeiffer, S.I., Pfeiffer, S.I., Eds.; Springer: New York, NY, USA, 2008; pp. 33-51.

32. Tidwell, R. A psycho-educational profile of 1,593 gifted high school students. Gift. Child Q. 1980, $24,63-68$. [CrossRef]

33. Maddux, C.D.; Scheiber, L.M.; Bass, J.E. Self-concept and social distance in gifted children. Gift. Child Q. 1982, 26, 77-81. [CrossRef]

34. Janos, P.M.; Fung, H.C.; Robinson, N.M. Self-concept, selfesteem and peer relations among gifted children who feel 'different'. Gift. Child Q. 1985, 29, 78-82. [CrossRef]

35. Moscovici, S. La Psychanalyse Son Image Son Public; Presses Universitaires de France: Paris, France, 1961.

36. Tavani, J.L.; Zenasni, F.; Pereira-Fradin, M. Social representation of gifted children: A preliminary study in France. Gift. Talent. Int. 2009, 24, 61-70. [CrossRef]

37. Räty, H. Debating educability: Diverging social representations of abilities in Finnish educational discourse. Soc. Psycho. Educ. 2014, 17, 457-469. [CrossRef]

38. Räty, H.; Mononen, N.; Pykäläinen, E. Essentialisms and social representations of intelligence. Soc. Psychol. Educ. 2017, 20, 915-927. [CrossRef]

39. Martínez, M.; Guirado, A. Alumnado con Altas Capacidades: Escuela Inclusiva: Alumnos Distintos, Pero no Diferentes; Graó: Barcelona, Spain, 2010.

40. García-Barrera, A.; De la Flor, P. Percepción del profesorado español sobre el alumnado con altas capacidades. Estud. Pedagóg. 2016, 42, 129-149. [CrossRef]

41. Valadez, M.D.; Zambrano, R.; Borges, A. Conocimiento de los profesores de aula y de apoyo en educación básica respecto a la definición de alumnos con aptitudes sobresalientes. Un estudio cualitativo. TALINCREA 2019, 5, 36-48.

42. Alonso, J. La educación de los alumnos con sobredotación intelectual. In Inteligencia, Creatividad y Talento: Una Inversión Para la Niñez en Riesgo, VII Congreso Bienal de la Ficomundyt, Lima, Perú; Alonso, J., Ed.; Ministerio de Educación y Ciencia de ESPAÑA: Madrid, Spain, 2008; pp. 37-64.

43. Reis, S.; Renzulli, J. Is there still a need for gifted education? An examination of current research. Learn. Individ. Differ. 2010, 20, 308-317. [CrossRef]

44. Hansen, J.B.; Feldhusen, J.F. Comparison of trained and untrained teachers of gifted students. Gift. Child Q. 1994, 38, 115-121. [CrossRef]

45. Siegle, D.; Powell, T. Exploring teacher biases when nominating students for gifted programs. Gifted Child Quarterly 2004, 48, 21-29. [CrossRef]

46. Tallent-Runnels, M.; Tirri, K. Teachers' attitudes toward gifted education: A cross-cultural study. In Proceedings of the ECHA Conference, Oxford, UK, 18-21 September 1998.

47. Rost, D.F. Giftedness: A risk or protective factor for the psycho-social development? Selected findings from the Marburg Giftedness Study. In Proceedings of the Congresso Internacional de ANEIS, Coimbra, Portugal, 13-14 May 2016.

48. Valadez, M.D.; Betancourt, J.; Flores, F.; Montero, R.; Borges, A. Exactitud de la Detección del Alumnado de altas Capacidades por Parte de sus Progenitores. Acción Psicológica 2020, under review. 
49. Wachelke, J. Social representations: A review of theory and research from the structural approach. Univ. Psychol. 2012, 11, 729-741. [CrossRef]

50. Cialdini, R.B. Influence. Science and Practice, 4th ed.; Allyn \& Bacon: Boston, MA, USA, 2001.

51. Pérez, J.; Aperribai, L.; Garamendi, L.; Borges, A. Representación Sobre las Altas Capacidades Intelectuales (Superdotación). 2019, unpublished assessment instrument.

52. Ely, K. Understanding the stereotypes against gifted students: A look at the social and emotional struggles of stereotyped students. Acad. Leadersh. Online J. 2007, 8, 56.

53. Baudson, T.G. The mad genius stereotype: Still alive and well. Front. Psychol. 2016, 7, 368. [CrossRef] [PubMed]

54. Guirado, A. Qué Sabemos de las Altas Capacidades? Preguntas, Respuestas y Propuestas para la Escuela y la Familia; Graó: Barcelona, Spain, 2015.

55. Gagné, F.; Nadeau, L. Dimensions of attitudes toward giftedness. In Gifted and Talented Children, Youth and Adult: Their Social Perspective and Culture; Roldan, A.H., Ed.; Trillium Press: Monroe, NY, USA, 1985; pp. 148-170.

56. National Association for Gifted Children. Myths about Gifted Students. Available online: https://www.nagc. org/myths-about-gifted-students (accessed on 26 July 2018).

57. Kauffman, J.M.; Hallahan, D.P. (Eds.) The Illusion of Full Inclusion: A Comprehensive Critique of a Current Special Education Bandwagon; PRO-ED: Austin, TX, USA, 1994.

58. Guirado, A.; Martínez, M. Alumnos con Altas Capacidades; Graó: Barcelona, Spain, 2010.

59. Cooper, C.R. Myth 18: It is fair to teach all children the same way. Gift. Child Q. 2009, 53, 283-285. [CrossRef]

60. Callahan, C.R. Myth 3: A family of identification myths. Gift. Child Q. 2009, 53, 239-241. [CrossRef]

61. Artiles, C.; Jiménez, J.E. Introducción a la Atención Educative del Alumnado con Altas Capacidades Intelectuales; Universidad de Las Palmas de Gran Canaria: Las Palmas de Gran Canaria, Spain, 2005.

62. Lorenzo-Seva, U.; Ferrando, P.J. Factor 9.2: A comprehensive program for fitting exploratory and semiconfirmatory factor analysis and IRT models. Appl. Psychol. Meas. 2013, 37, 497-498. [CrossRef]

63. Samejima, F. Estimation of latent ability using a response pattern of graded scores. Psychom. Monogr. Suppl. 1969, 34, 1-97. [CrossRef]

64. Muñiz, J.; Fidalgo, A.M.; García-Cueto, E.; Martínez, R.; Moreno, R. Análisis de los Ítems; La Muralla, S.A.: Madrid, Spain, 2005; Volume 30, pp. 79-131.

65. Valadez-Sierra, M.D.; Galán-Leyte, M.G.; Borges-Del Rosal, A.; López-Aymes, G.; Ávalos-Rincón, A.; Zambrano-Guzmán, R. Identification and intervention for gifted and talented children, from the speech of elementary teachers in Guanajuato. Rev. De Educ. Y Desarro. 2015, 34, 35-42.

66. Pérez, L. Superdotación y familia. Faisca 2004, 11, 17-36.

67. Borges, A.; Rodríguez-Naveiras, E.; Rodríguez-Dorta, M. Ajuste personal y social del alumnado de altas capacidades: Evidencias empíricas y respuesta educativa. In Educação de Superdotados e Talentosos; Piske, F., Stoltz, T., Costa-Lobo, C., Rocha, A., Vásquez-Justo, E., Eds.; Jurua: Oporto, Portugal, 2018; pp. 45-62.

68. Hernández-Jorge, C.; Borges, A. Entorno escolar del alumnado de altas capacidades intelectuales frente a sus compañeros de distinto nivel de inteligencia. Faísca 2010, 15, 36-49.

69. Peairs, K.F.; Sheppard, C.S.; Putallaz, M.; Costanzo, P.R. Leader of the pack: Academic giftedness and leadership in early adolescence. J. Adv. Acad. 2019, 30, 416-440. [CrossRef]

70. Ogurlu, Ü.; Emir, S. Effects of a leadership development program on gifted and non-gifted students' leadership skills. EJER 2014, 55, 223-242. [CrossRef]

71. Campbell, D.T. Stereotypes and the perception of group differences. Am. Psychol. 1967, 22, 817-829. [CrossRef]

72. Tajfel, H.; Turner, J.C. An integrative theory of intergroup conflict. In The Social Psychology of Intergroup Relation; Austin, W.G., Worchel, S., Eds.; Broods/Cole: Monterey, CA, USA, 1979; pp. 33-47.

73. Cuddy, A.J.C.; Fiske, S.T.; Glick, P. The BIAS map: Behaviors from intergroup affect and stereotypes. J. Pers. Soc. Psychol. 2007, 92, 631-648. [CrossRef] [PubMed]

74. Vaillant, D. Construcción de la Profesión Docente en América Latina. Tendencias, Temas y Debates; PREAL, Programa de Promoción para la Reforma Educativa en América Latina y el Caribe (31); Grupo de Trabajo sobre Profesionalización Docente de PREAL: Montevideo, Uruguay, 2004.

75. Aperribai, L. Evaluación de un programa de formación en altas capacidades intelectuales para profesionales de la educación. TALINCREA 2019, 5, 62-72. 
76. Borges, A.; Hernández-Jorge, C.; Rodríguez-Naveiras, E. Comportamientos parentales en familias con superdotados. Faísca 2006, 11, 48-58.

77. Borges, A.; Hernández-Jorge, C. Gifted child in the family: Early detection of giftedness. TALINCREA 2018, 4, 40-48.

78. Flores-Bravo, J.F.; Valadez-Sierra, M.D.; Borges-Del Rosal, A.; Betancourt-Morejón, J. Main concerns of parents of children with high abilities. Rev. De Educ. Y Desarro. 2018, 47, 115-122. 